Interview

\title{
"We've had enough of being trapped in this derelict pondok of history": An interview with Zoë Wicomb
}

\section{Zoë Wicomb \& Yuan-Chih Yen}

Zoë Wicomb, one of South Africa's most brilliant and celebrated writers, needs no introduction. Her latest novel, Still Life, uses the story of a struggling author who calls on several historical figures and fictional characters to help her write a biography of Thomas Pringle, one of the 1820 settlers who later became known in South Africa as the "father" of South African poetry, to explore the legacies of settler colonialism as well as the uses and limits of narrative and notions like truth. Yuan-Chih Yen interviewed Wicomb over email in April 2021.

YY: A host of real and fictional characters are resurrected in your latest novel Still Life to think through the ambiguous figure of Thomas Pringle, who was both a settler and ostensibly an abolitionist. You mention in your interview with Carla Lever and Nal'ibali that "[t] hese characters allow [you] to interrogate Pringle and the colonial project, and solve [your] problem of how to write his history". What is it about Pringle and his legacy that drew you to him, and why did you find him-rather than a writer like Olive Schreiner or Pauline Smith - a productive foil to reflect on the "contradictions and dissimulations" (246), as you put it in the novel, of colonialism in South Africa?

ZW: Perhaps unfair to call Pringle an "ostensible abolitionist"; he was indeed a humanitarian who not only worked as Secretary for the Antislavery Society but was also responsible for getting Mary Prince's story recorded and published. Back in London he campaigned for the repatriation of the Khoesan chief David Stuurman who had been transported to New South Wales - even if Stuurman died just before his release. I suppose the ambiguities of Pringle's life and works tell us something about how humanitarianism itself was implicated in race and empire. It was Pringle's life and his political involvement that interested to me. I am not a fan of his poetry, but there is something piquant about him being Father of South African Poetry when no one in his native Scotland (where I live) has heard of him. And I didn't set out to reflect on the contradictions and dissimulations of colonialism. Pringle's is a documented life, but it was really Hinza's undocumented life that propelled the novel. Examining the ambiguous "adoption" of a Tswana boy perhaps could not fail to expose the fabric of colonialism, not if you look at it from the boy's point of view.

YY: The reluctant female writer - who is assigned with the "task of restoring Mr P" by the "ghostly figures" (14) of Mary Prince, whose narrative of enslavement Pringle helped publish, and Hinza Marossi, Pringle's adopted Tswana son-dramatises the struggles and challenges of writing. This might be read autobiographically, as you indeed mention in your interview with Izak de Vries that you "find it impossibly difficult to write, and it is not until [you've] beaten out a first draft, and thus finally discover what the novel is really about, that there is any pleasure to be found in the various redrafts". What motivates you to push through with the writing to tell the stories that you do, to consider the "ways in which an absence in a story could be fashioned in an alluring manner" (250), as the literary agent Belinda puts it in the novel?

Zoë Wicomb is the internationally acclaimed author of six works of fiction and one collection of essays, as well as a winner of the 2013 Windham-Campbell Literature Prize.

Yuan-Chih (Sreddy) Yen obtained their MA from the University of the Witwatersrand, Johannesburg, South Africa and is currently a PhD student in the Department of English, Weinberg College of Arts and Sciences, Northwestern University, Evanston, IL, US.

Email: yuan-chihyen2025@u.northwestern.edu

(iD https://orcid.org/0000-0002-5679-4570

D0l: https://doi.org/10.17159/tl.v58i2.11069 
ZW: Yes, dramatizing the struggle with writing could be seen as autobiographical, but since my problems with writing apply to all my fiction, it begs the question of why this strategy for this project. I can't answer that question. The strategy itself evolves from messing about with my material, trying out different ways of getting started.

I also can't explain why I push through with the writing, except that it seems to be what living is about, pushing at the limits of one's capabilities. I am not especially well endowed, and perhaps it was growing up under the strictures of apartheid that my earliest lessons were about probing those limits. Also a matter of self-respect, I suppose, to persevere. If one has the ability to conceive of a project, no matter how inchoate, then you simply have to see it through, even if the end product reveals your limitations as a writer. Given that I don't know what I'll end up with, what the story is really about, I am immersed in the process, which keeps at bay concerns about how the product will be viewed by others. My publisher, who is the first person to see what I've written, decides whether it could be published or not.

Belinda is not entirely correct about an absence. There is much about the story that pre-exists; the problem is how to tell it and from which angles; besides, my stories sadly fall short of being alluring.

YY: In the same interview with De Vries, you note that you "did not want the ready-made generic conventions of the historical novel". Could you say a little more about what you think are the uses and the limits of that genre? In addition, how did you come to settle on what we might call, following Saidiya Hartman, the method of "critical fabulation" (11) in your attention to Hinza Marossi?

ZW: I was referring to the standard historical novel, a genre that I am unable to read. It is not of interest to me. There is undoubtedly much skill involved, but I don't see the point of painstakingly recreating the world of that past and being faithful to the least detail. Uninterested in verisimilitude, I'd rather read an historical text than a fictionalised account. I understand that the writer could shift the focus here or there, shine a torch into dark, forgotten, unexplored corners and so on, but it all falls within the artifice of verisimilitude. Of course, the genre has latterly been manipulated to the extent that Still Life itself appeared in the New York Times list of ten best historical novels of 2020. Gratifying, but puzzling to me. Perhaps it is because of my struggles with writing that I'd rather come clean and present the constructedness of the text. Also, I want to engage with the fact that the historical material is of interest to me at the time of writing so that there is dialogue between past and present inscribed in the text.

I'm afraid I haven't read Hartman's work. It sounds interesting, but if "critical fabulation" is about combining research, critical theory and fiction, then that is not what I do. I do not build upon critical theories or concepts; rather, I explore lives and to do so I take liberties with the given information about my characters. Hinza, in fact, died not long after arriving in England; I allow him to live as a young man in the twenty-first century who, like any young man, questions his strange origins, rather than one who demonstrates or embodies a theory. Hinza says that he is born out of a text, by which he means Pringle's poem, but my Hinza is also born out of my process of writing. I don't want to present writing as a mysterious or magical thing, but at the same time, I don't know how my various attempts evolve into the final representation.

YY: What is the relationship between the "derelict pondok of history", as Mary elegantly puts it, and the "house of fiction"(10) that both the writer in Still Life and you yourself are trying to build?

ZW: It is not my place to comment on the meaning of my own work, so I'll be brief. The narrative starts with a makeshift shelter in which an author finds herself trapped by characters who demand that she write their story. The "pondok", Afrikaans for the commonly found South African shack constructed by the poor out of scrap materials, as well as the reference to Henry James's "house of fiction" (with its many windows) are riffs on a makeshift shelter. Hopefully, they open up meanings about both history and ways of writing or approaching fiction.

YY: More that 15 years ago now, literary critic Ashraf Jamal provocatively suggested in Predicaments of Culture in South Africa that the South African cultural imaginary is still stuck in rigid and inadequate categories of identification which stem from the divisive logic of cultural solidarity and difference established by apartheid. You expose and question in all your work the discursive constructedness of such categories and the power dynamics that inhere in these investments, and in Still Life particularly, the time-travelling writer-critic Sir Nicholas Greene from Virginia Woolf's Orlando somewhat ironically exclaims to Hinza that "this is the age of identity obsession, of racial authenticity, of seeking out real roots" (121). What do you think are the uses and abuses of identity politics in contemporary South Africa? 
ZW: Identity politics is the inevitable outcome of both historical apartheid and the resistance movement. Some conditions of the past may be changing, but sedimentation has taken place and it can't be sluiced away when so many historical inequities remain in place. The following may be a crude simplification and there are indeed examples of contrary positions, but one can't help registering certain trends. Black nationalism then, a requisite for a liberation movement, digs in its heels and finds new forms of assertion in toxic xenophobia; coloureds select their Khoesan roots, deny miscegenation as well as historical genocide, and take to their bow and arrows; whites deny their privilege, and speak of "reverse apartheid" to refer to bias against them. Bias there may be, but it so happens that we don't have homelands for whites; they do not by law earn less than blacks; they do not have separate, inferior amenities, nor are they barred from voting or from criticizing the government; they are not subjected to a range of indignities and restrictions; indeed, the country's wealth is kept safely in their hands, in spite of cries about black corruption. What then, one might ask, do they think apartheid was about? (I have recently written to the Collins English Dictionary to object to their absurd entry of "reverse apartheid"). Antjie Krog's questioning of entrenched attitudes within her own group is routinely met by sighs and shaking of sophisticated heads, weary of such carping. Not only are we stuck in Jamal's "divisive logic of cultural solidarity and difference established by apartheid", there are also strange new manifestations. What does one make, for instance, of the new spelling of place names in the Western Cape, where the once preferred Afrikaans vowel "y" has been replaced by the Dutch vowel "ij"?

Attitudes towards race may well be changing amongst the younger generation, but the economic reality prevents that from making a difference. I'm hard pressed to think of any uses for identity politics in South Africa where there are so many different vying constituencies. In countries like Britain where black people are a minority, identity politics serves to insist on their presence and to lobby for legislative change. I'm not sure what it achieves in South Africa with its ANC government where it manifestly does not and perhaps cannot lead to the levelling of social inequities.

YY: Mary asks a pertinent question in Still Life: "How hard can it be, the skill of inserting yourself into the world of others?" (221). Do you have any suggestions for how we might go about this difficult task of interacting with the other ethically? In your first novel, David's Story, a waiter that the titular character David encounters muses that "in the New South Africa we need to communicate with each other" (164). How might we begin to foster productive conversations across identitarian divisions in South Africa?

ZW: I really don't have a clue. I don't remember David's Story, but the words of the waiter sound as if they're meant to be read ironically. Hinza's experience in the Cape, in fact, shows that it is hard; although well-meaning, he finds it impossibly difficult to interact with those who occupy different worlds. Mary's position is a truism. Structural inequities and racism exist. The privileged protect their worlds by making them impenetrable, and the poor, necessarily suspicious, protect their own vulnerable, provisional worlds by keeping mum. Hinza, the metropolitan, finds it difficult to speak to either of those groups.

Our bourgeois notion of delicacy, which is Hinza's problem (also my own), feeds into and perpetuates the inability to talk to teach other. We have much to learn from the following ideas about anti-racism in the USA, even if they sound crass: there is no such thing as neutrality or non-racism; only personal accountability and action count as anti-racist. The current movements, in which white people march noisily and carry placards of "Black Lives Matter", openly showing solidarity and acknowledging racism, or where black people in the UK topple statues of slavers, demanding that authorities acknowledge racism and hypocrisy, seem to be the only way. This rude hollering is, of course, a huge step for those of us schooled in delicacy and refined sensibilities, but it is precisely the very opposition of crassness/delicacy that needs to be deconstructed. In whose interest has such an opposition been constructed? Whose privilege does it protect? We underestimate Meghan Markle's courage when she resorts to the "vulgarity" of speaking to Oprah on the subject of racism that is taboo in refined aristocratic circles, a taboo adopted by the middle classes with doubled anxiety. 
YY: You indicated in the interview with Andrew van der Vlies (published in the collection of your critical essays that he edited) that you feel that at the moment, so-called theory from the South seem to be more about the need for it, rather than articulation of actual theories. If the South is as the Comaroffs claim a space of experimentation, I look forward to such experimentation, such revitalizing knowledge production. There is an encouraging optimism about their idea of conversion from revolution to revelation and of social regeneration, but the proposed quest for wisdom and redemption is as yet hard to discern in South African political culture. (277) How do you see your own body of work as contributing to the endeavour to bring about this space of experimentation and social regeneration, and who would you say are some of the other (South) African writers and thinkers doing similar work?

ZW: First and foremost, I am less sanguine about writers of fiction bringing about social regeneration, and so do not see myself making any contribution in that respect. In fact, is writing itself not rather a product of social regeneration?

A shift from slavishly following the West to attend to the conditions and practices of the global South is a welcome one from which there is undoubtedly knowledge to be gained. My problem perhaps lies with the redundant word "theory" to which the humanities have become addicted and on which we have come to rely for gravitas. (Which is not to say that there have not been groundbreaking theories that have shifted the ways in which we think.)

But on further reflection, I can't imagine how revolution is converted to revelation or even what it might mean in South Africa or elsewhere. In my pessimistic old age, I see only the nasty reality of economics, of the poor stumbling in poverty and dying undignified Covid deaths as they queue at overflowing hospitals, of the third world suffering effects of climate change brought about by over-development. Literary experimentation (carried out by those like myself in our centrally heated houses) seems pathetic in the face of the unsung who work tirelessly for survival in places ravaged by climate change, or a Greta Thunberg who overcomes her personal problems to take on these challenges.

YY: Lastly, could you tell us a little bit about what you're working on at the moment?

ZW: I cannot speak about current work. I can't be sure that my scribblings will culminate in anything. Another novel seems out of the question.

\section{Works Cited}

De Vries, Izak. "Still life, An Interview with Zoë Wicomb." LitNet. 25 Nov. 2020. https:/www.litnet.co.za/still-life-aninterview-with-zoe-wicomb/.

Hartman, Saidiya. "Venus in Two Acts." Small Axe vol. 12, no. 2, 2008, pp. 1-14.

Jamal, Ashraf. Predicaments of Culture in South Africa. U of South Africa P, 2005.

Lever, Carla \& Nalibali. “I Am Not Alone in Questioning History”. Sunday Times. 19 Oct. 2020. https://www.timeslive.co.za/ sunday-times/books/news/2020-10-19-i-am-not-alone-in-questioning-history-zo-wicomb/.

Van der Vlies, Andrew. "Intertextualities, Interdiscourses, and Intersectionalities." Race, Nation, Translation, edited by Andrew van der Vlies. Yale U P, 2018. pp. 261-81.

Wicomb, Zoë. David's Story. Kwela, 2000. Still Life. The New Press, 2020. 